\title{
Professionalism: Logging on to tell your doctor off
}

$\mathrm{P}$ atients might not be comfortable calling out their doctors for being unprofessional in person but appear to have few qualms about expressing their frustrations online. Ratings websites for physicians are growing in number and popularity. Are they good feedback tools that help doctors improve their professionalism? Or are they merely a place for malcontents to unjustly - and anonymously bash good physicians?

Perhaps they are a little of both. Whatever purpose they serve, doctors would be remiss to ignore them.

"This trend is going to continue. Online reputation is just as important as reputation in the community. It's really to every clinician's benefit to be proactive and manage their online reputation. I tell every doctor to Google their names once a week," says Dr. Kevin Pho, who practises internal medicine in Nashua, New Hampshire, and serves as "social media's leading physician voice" on his popular website (kevinmd.com).

"If you don't define yourself online, someone else is going to do it for you. It doesn't take a lot of time to do this," adds Pho. "All they need is to have some kind of social media profile, a page that will get ranked in Google. That will put them in control of their online digital footprint."

Physicians can bolster their social media presence by joining multiple platforms, including Facebook, Twitter and LinkedIn. The stronger their selfdirected Internet profile, the less likely that a third-party ratings site will pop up as the top result in a search engine. Of course, doctors could also take a decidedly low-tech approach to countering negative reviews: by never being rude to patients.

"Any doctor can be nice and be polite if they want to, and I think they should. It doesn't cost them anything," says John Swapceinski, a computer programmer and cofounder of RateMDs.com, a physician ratings service based in San Jose, California. "It's really a customer

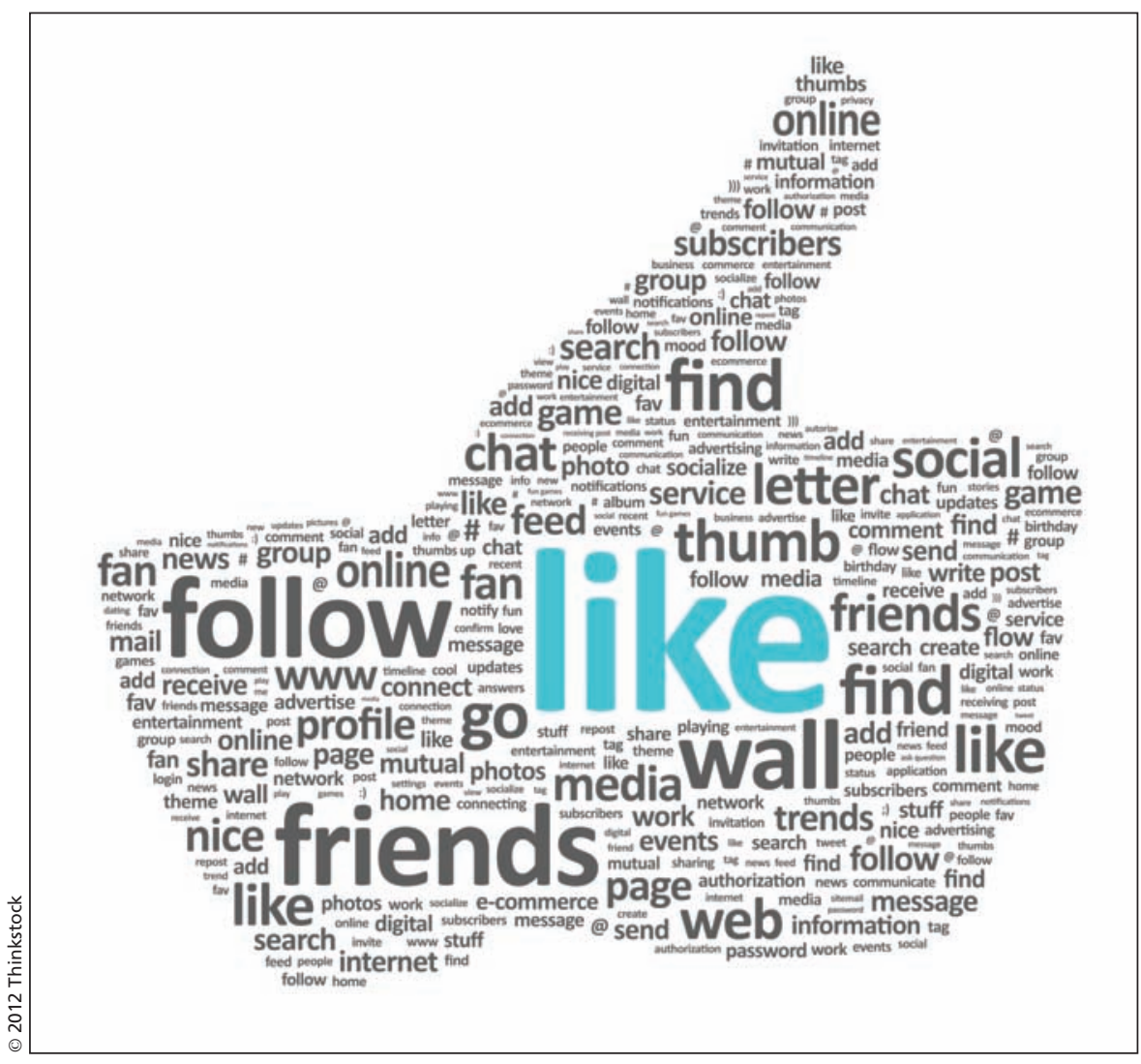

One way doctors can improve their online reputations is to encourage happy patients to post positive comments on physician rating sites.

service issue. If the checkout girl at a grocery store is mean to me every time, even if the products are fine, I'm going to go somewhere else."

Swapceinski cofounded RateMDs in 2004 , viewing it as a natural companion to the popular ratings site for professors he had already established. "I was thinking of other professional services that needed ratings. Medicine and physicians came to mind. It really is the most important profession," he says. "Anything that people spend time or money on can benefit from having ratings about them. People like to talk about their experiences."

Indeed they do. RateMDs receives about 2 million visits a month, according to Swapceinski, and traffic is doubling every year. Canadian patients are a particularly opinionated lot. Though the United States has far more doctors, up to $40 \%$ of users hail from Canada. Swapceinski estimates that somewhere in the neighbourhood of $90 \%$ of Canadian doctors have at least one rating on the site, compared to around $20 \%$ of US physicians.

Some doctors have actually expressed gratitude for RateMDs, thanking Swapceinski for the valuable feedback it provides. Many of the most common patient complaints are on service-related matters — rude receptionist, inadequate parking, prehistoric magazines in the waiting room - that aren't top of mind for physicians.

But a lot of doctors find little to love about ratings websites. "Some people can't handle criticism at all, and I do see that more in the doctor field than in the professor field," says Swapceinski. "A lot of the doctors are not used to being questioned and they don't like it." 
Swapceinski and his colleagues have strived to make RateMDs a better service. They now delete duplicate ratings from a single user, so no individual can single-handedly ruin a doctor's reputation. If possible, they track physicians who move to new areas with hopes of escaping their pasts. And though people can comment anonymously, there is still a degree of accountability. Swapceinski receives, on average, one subpoena a month from a lawyer for a doctor intending to sue a person for making a false accusation on RateMDs, and he will surrender that user's IP address.

"I have no problem with that," says Swapceinski. "If someone slanders a doctor and it's false, they should be punished."

Physicians who feel they are being unfairly maligned can also respond to online ratings, though they have to be careful about it. Responding quickly in anger might lead them to inadvertently breach doctor-patient confidentiality. And some comments just aren't worth responding to anyway, says Dr. Mike Woo-Ming, a physician turned Internet business consultant and the CEO of RepMD (repmd.com), a company based in San Marcos, California, that helps physicians improve their online reputations.

"If someone is just calling you every name in the book, you might not want to respond," says Woo-Ming. "But it is fine to respond to a review in a way that shows you care about the patient and indicates you are striving to improve."

Merely posting the occasional rebuttal, however, is hardly enough to combat negative reviews, many of which may not even have been written by patients, says Woo-Ming. Because it is anonymous, a nasty rating could very well be the work of a disgruntled former employee or a physician competing for the same patients. Even legitimate reviews tend not to depict an accurate picture of a medical practice, because most people who are happy with their doctors don't bother to post comments.

"What's frustrating for some of these doctors is that they may have been in practice for 40 years and have only two comments online, but both are negative," says Woo-Ming.

A handful of negative ratings, without a healthy supply of positive ones to counter them, can cause harm not only to a physician's reputation, but also to their income. It can serve as useful ammunition for malpractice lawyers. It can make it harder to sell a practice. If you happen to take over a practice from a poorly rated doctor, that reputation tends to linger.

RepMD, which has hundreds of clients across the United States and Canada, helps physicians improve their online reputations in several ways. WooMing would not disclose how much he charges for reputation management, writing in an email that "it really is dependent on how bad the situation is, and we price accordingly, and a specific dollar value could give the wrong impression."

Others in the reputation management industry appear to charge on the order of US $\$ 1000-$ US $\$ 1500$ per month to polish tarnished characters. Reputation Hawk (www.reputationhawk.com) and Online Reputation Manager (www.onlinereputationmanager.com) both display prominent "request a quote" buttons on their websites, and the latter states its average price is around US\$1000 a month. The prices at Reputation Managers (reputationmanagers.com) start at US\$1500 a month, but also vary widely according to the complexity of the job.

Services provided by RepMD include requesting that ratings websites take down particularly egregious reviews (such as unsubstantiated claims of criminal activity), assistance in setting up physician websites (that can be linked to from ratings websites) and creation of an internal patient feedback process in medical practices (which will solicit positive comments to be posted to various physician ratings websites).

"Most doctors don't take the time to find out what their patients are actually saying about their experiences. Doctors need to realize they are in the customer support business," says Woo-Ming. "Patient satisfaction is going to become even more important, and your online reputation is going to be of greater importance. It's not going to go away." - Roger Collier, CMAJ

CMAJ 2012. DOI:10.1503/cmaj.109-4205

Editor's note: Seventh in a multipart series on medical professionalism.

Part I: The "good doctor" discussion (www.cmaj.ca/lookup/doi/10.1503 /cmaj.109-4200).

Part II: What is it? (www.cmaj.ca /lookup/doi/10.1503/cmaj.109-4211).

Part III: The historical contract (www.cmaj.ca/lookup/doi/10.1503 /cmaj.109-4230).

Part IV: Can it be taught?

(www.cmaj.ca/lookup/doi/10.1503 /cmaj.109-4232).

Part V: Social media outreach (www.cmaj.ca/lookup/doi/10.1503 /cmaj.109-4207).

Part VI: Social media mishaps (www.cmaj.ca/lookup/doi/10.1503 /cmaj.109-4209). 